\title{
Human Health Risk Assessment of Heavy Metals in the Urban Road Dust of Zhengzhou Metropolis, China
}

\author{
Muhammad Faisal ${ }^{1}$, Zening Wu ${ }^{1,2}$, Huiliang Wang ${ }^{1,2}, *$, Zafar Hussain ${ }^{1,3}$ and Muhammad Imran Azam 4 \\ 1 College of Water Conservancy Engineering, Zhengzhou University, Zhengzhou 450001, China; \\ engineerfaisi@gs.zzu.edu.cn (M.F.); zeningwu@zzu.edu.cn (Z.W.); zafar775@yahoo.com (Z.H.) \\ 2 Zhengzhou Key Laboratory of Water Resource and Environment, Zhengzhou 450001, China \\ 3 Water Resources Section, Ministry of Planning, Development \& Special Initiatives, Islamabad 44000, Pakistan \\ 4 Hydropower and Water Resources Section, Zeeruk International (PVT), Islamabad 44000, Pakistan; \\ drimran@zeeruk.com \\ * Correspondence: wanghuiliang@zzu.edu.cn
}

check for

updates

Citation: Faisal, M.; Wu, Z.; Wang, H.; Hussain, Z.; Azam, M.I. Human Health Risk Assessment of Heavy Metals in the Urban Road Dust of Zhengzhou Metropolis, China. Atmosphere 2021, 12, 1213. https:// doi.org/10.3390/atmos12091213

Academic Editors: Dmitry Vlasov, Omar Ramírez Hernández and Ashok Luhar

Received: 12 August 2021 Accepted: 15 September 2021 Published: 17 September 2021

Publisher's Note: MDPI stays neutral with regard to jurisdictional claims in published maps and institutional affiliations.

Copyright: (c) 2021 by the authors. Licensee MDPI, Basel, Switzerland. This article is an open access article distributed under the terms and conditions of the Creative Commons Attribution (CC BY) license (https:// creativecommons.org/licenses/by/ $4.0 /)$.

\begin{abstract}
The goal of this research is to assess hazardous heavy metal levels in $\mathrm{PM}_{2.5}$ fractioned road dust in order to quantify the risk of inhalation and potential health effects. To accomplish this, Inductively Coupled Plasma Mass Spectroscopy (ICP-MS) was used to determine concentrations of eight heavy metals $\left(\mathrm{Cr}, \mathrm{Cu}, \mathrm{Ni}, \mathrm{Zn}, \mathrm{Cd}, \mathrm{As}, \mathrm{Pb}\right.$, and $\mathrm{Hg}$ ) in the $\mathrm{PM}_{2.5}$ portion of road dust samples from five different land use areas (commercial, residential, industrial, parks, and educational) in Zhengzhou, China. The following were the average heavy metal concentrations in the city: $\mathrm{Cr}$ $46.26 \mathrm{mg} / \mathrm{kg}$, Cu $25.13 \mathrm{mg} / \mathrm{kg}$, Ni $12.51 \mathrm{mg} / \mathrm{kg}$, Zn $152.35 \mathrm{mg} / \mathrm{kg}$, Cd $0.56 \mathrm{mg} / \mathrm{kg}$, As $11.53 \mathrm{mg} / \mathrm{kg}$, $\mathrm{Pb} 52.15 \mathrm{mg} / \mathrm{kg}$, and $\mathrm{Hg} 0.32 \mathrm{mg} / \mathrm{kg}$. Two pollution indicators, the Pollution Index (PI) and the Geoaccumulation Index ( $\left.\mathrm{I}_{\text {geo }}\right)$, were used to determine the degree of contamination. Both PI and $\mathrm{I}_{\text {geo }}$ indicated the extreme pollution of $\mathrm{Hg}$ and $\mathrm{Cd}$, while PI also ranked $\mathrm{Zn}$ in the extreme polluted range. The US Environmental Protection Agency (USEPA) model for adults and children was used to estimate health risks by inhalation. The results identified non-carcinogenic exposure of children to lead ( $\mathrm{HI}>0.1)$ in commercial and industrial areas. Both children and adults in Zhengzhou's commercial, residential, and park areas are exposed to higher levels of copper $(\mathrm{Cu})$, lead $(\mathrm{Pb})$, and zinc $(\mathrm{Zn})$.
\end{abstract}

Keywords: geo-accumulation index; heavy metals; road dust; inhalation; resuspension; cancer

\section{Introduction}

Heavy metals pose a serious threat to human health, and their increasing presence in urban road dust warrants a health emergency. Studies reveal that the accumulation and spread of heavy metals in urban road dust is caused by both anthropogenic and natural factors [1]. Major anthropogenic sources of heavy metals include industrial, household and traffic emissions, while natural sources include soil particle deposition, resuspension, weathering, and erosion [2]. In general, urban areas are more vulnerable to heavy metal contamination compared to rural areas, given the population density and presence of diverse sources of pollution [3]. There has been a worldwide increase in pollutants owing to urban dust, which constitutes a genuine environmental and public health hazard [4].

Environmentalists believe that heavy metal contamination is a significant hazard to the environment [5], and during the previous two decades, a crisis happened with the increasing buildup and spread of heavy metals [6]. There is evidence that chronic deposition of metals in metropolitan environments can operate as a secondary pollution source, resulting in public health issues. Because of their weakened or underdeveloped immune systems, the elderly and children are generally considered the most vulnerable groups. Unintentional intake of road powder, most of which goes from dirty hands to nasal passages, can cause heavy metals to be transferred to the human body [7-9]. Exposure to 
high amounts of ambient particulates (PMs) can induce severe respiratory effects [10]. In prior research, the respiratory system has been found to be more easily and more seriously affected by $\mathrm{PM}_{2.5}$ than other human body systems [11]. Children once again make up the group more susceptible to heavy metals, which can negatively influence their natural growth [12].

The resuspension of dust belonging to the fraction of $\mathrm{PM}_{2.5}$ is predominantly a cause of exposure of humans to heavy metals $[13,14]$. Water-soluble heavy metals have been found to contribute significantly to $\mathrm{PM}_{2.5}$ and $\mathrm{PM}_{10}$ emissions in a variety of locales, particularly in urban areas [15]. It has been reported in previous research that re-suspended dust is primarily responsible for the presence of $\mathrm{PM}_{1}, \mathrm{PM}_{10}$, and $\mathrm{PM}_{2.5}$ fractions. Their traffic emission percentages were found to be $3 \%, 36 \%$, and $14 \%$, respectively [16]. Moreover, dust particles with sizes $<100 \mu \mathrm{m}$ can re-suspend due to winds and the movement of vehicles [17]. This kind of resuspension is particularly dangerous as heavy traffic flows do not only move the road dust, but are also responsible for the emission of metals such as $\mathrm{Cu}, \mathrm{Zn}, \mathrm{Fe}$, and $\mathrm{Pb}$ [18]. The situation becomes worse in the case of unmaintained vehicles, not fully meeting the requirements of road-worthiness as is the situation in most of the developing countries. Hence, the production level of $\mathrm{PM}_{2.5}$ is increased significantly $[19,20]$.

In urban areas, parks, leisure places, and city squares are the centers of recreational, sporting, and commercial activities. As the living standard and lifestyles in China are improving, people are now more conscious about their health and entertainment, and there is increased anthropogenic activity at such places. Industrial areas are considered even more polluted due to the emission of hazardous gases. So, the health of people who live around these places are affected by the poor quality of environment. The dust containing heavy metals makes its way to the human body through inhalation, resuspension, ingestion, and dermal contact, culminating into serious health issues. That is why it is important to assess and mitigate the pollution levels and their effects on human health.

The main focus of this study is the assessment of health risk caused by $\mathrm{PM}_{2.5}$ fraction of road dust. For this purpose, samples were collected from 29 locations that included different functional areas, such as industrial, residential, parks, educational, and commercial areas of Zhengzhou city and the capital of the Henan province in China. The intention behind choosing these areas was to include every prospect of environment where normal human beings come in contact with road dust. In previous studies, mostly the biggest cities received the attention of researchers for road dust pollution analysis, and minor attention was paid to medium or small cities [21,22]. As a result, despite being an economic, educational, industrial, and transportation center in China's central plains, Zhengzhou was overlooked. The key aims of this research, which is concentrated on the Zhengzhou metropolitan area, are as follows: (1) to find out the heavy metal concentrations related to traffic emissions of fraction $\mathrm{PM}_{2.5}$ from the road dust of different functional areas; (2) assessment of the pollution degree using pollution indices, and (3) health risk assessment using risk carcinogenic (CR), and Hazard Index (HI) methods for old adults and children $[23,24]$.

\section{Materials and Methods}

\subsection{Study Area Background}

As shown in Figure 1, the capital of Henan Province, Zhengzhou $\left(34^{\circ} 45^{\prime} 50.4^{\prime \prime} \mathrm{N}\right.$, $\left.113^{\circ} 41^{\prime} 2.4^{\prime \prime} \mathrm{E}\right)$, located in the megalopolis of the Central Plain, is an important commercial, transport, and logistics hub of central China. The city lies at the foot of the Funiu Mountains on the northeastern side. To the west, it is adjacent to high lands; to the east, it is encompassed by intermediate and lower terrain [25]. 


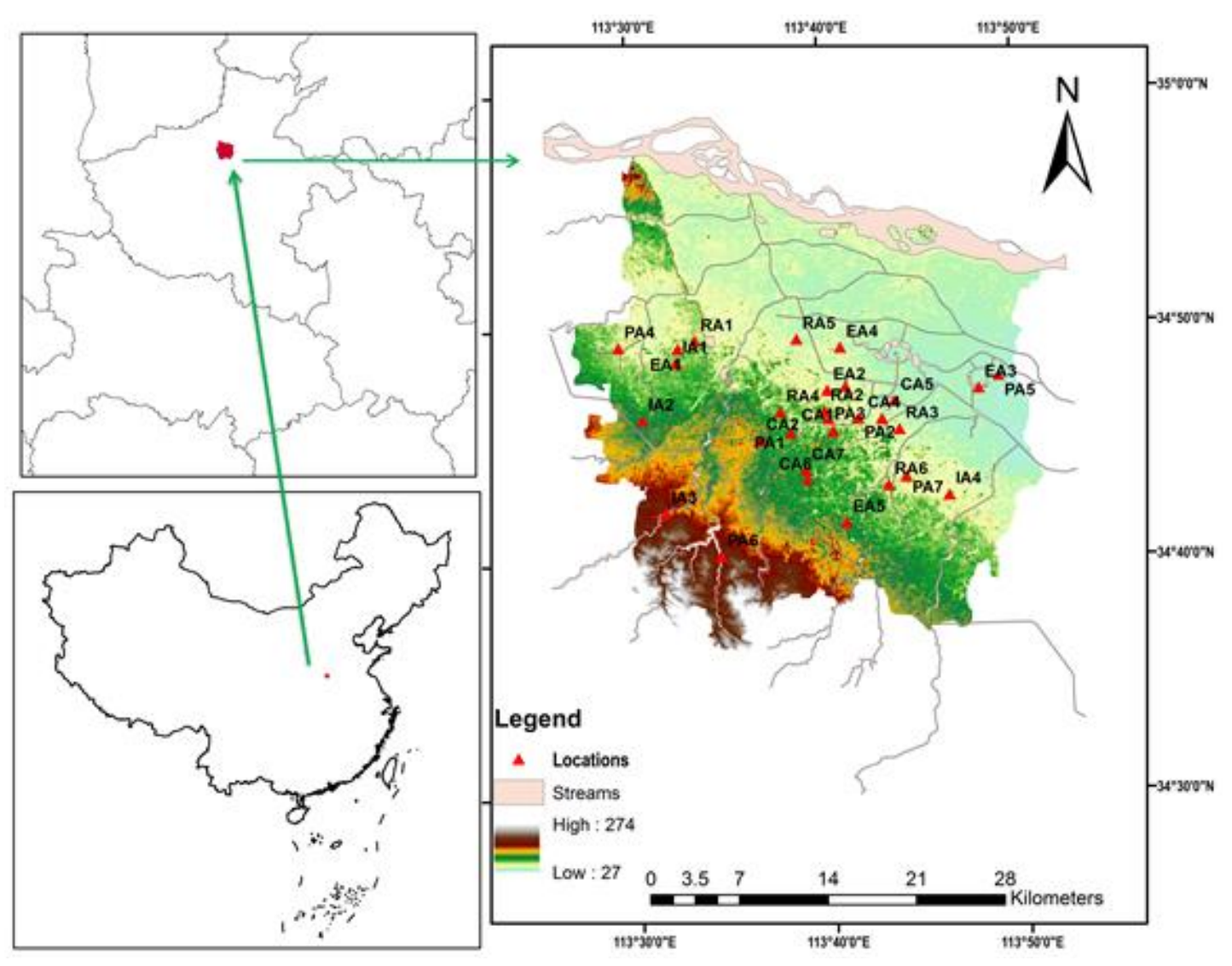

Figure 1. Study Area of Zhengzhou city.

The town has a moderate continental mountain climate in the northern zone. The yearly average temperature is 15.6 degrees Celsius, and the annual average precipitation is $542.15 \mathrm{~mm}$. A monthly average temperature is $25.9^{\circ} \mathrm{C}$ in the warmest month of August, while a monthly average temperature was $2.15^{\circ} \mathrm{C}$ during the coldest month of January [26]. Despite the fact that there are four different seasons, the summers and winters are of significantly longer durations [27].

Zhengzhou's geographic location, natural resources, cultural glory, political prominence, administrative stature, historical splendor, and significance continue to draw an overwhelming number of visitors and inhabitants. In December 2019, the city's population was anticipated to be 10.350 million people [28]. It was also projected that the city had more than 4,500,000 authorized motor cars [29] and 3,000,000 un-registered automobiles [30]. Each of these features of urbanism contributes to an increase in carbon footprint and the emergence of environmental repercussions that are currently being observed in the city.

\subsection{Sampling and Laboratory Analysis \\ 2.2.1. Sample Collection}

Twenty-nine locations were selected in Zhengzhou city that cover almost all the important places of different functional nature and the busiest roads, serving the maximum population (adults, patients, and children) of the city, comprising of those directly exposed to road dust pollution. Three samples of road dust were collected from each location: one sample from the center of the road, the second from the side of the road, and the third from the front of building areas near that road. In this way, eighty-seven samples in total were collected from twenty-nine locations, including five educational areas, four industrial areas, six residential areas, seven commercial areas, and seven park/leisure areas. A plastic brush was used to collect the road dust with the help of a pan and then collected into the plastic bags. The quantity of the dust samples was $>150 \mathrm{~g}$ from one sampling point $[31,32]$. 
After that, all the samples were shifted to the laboratory for analysis and kept for at least one week for drying purposes [33].

\subsection{2. $\mathrm{PM}_{2.5}$ Preparation and Total Metal Concentration}

For the preparation of $\mathrm{PM}_{2.5}$, Teflon filters were used with a size of $47 \mathrm{~mm}$ to acquire the inhalable segment of the $\mathrm{PM}_{2.5}$ of road dust [34]. Prior to this process, all the Teflon filters $(47 \mathrm{~mm})$ were dried out in a vacuum freeze dryer at $150{ }^{\circ} \mathrm{C}$ and kept for $6 \mathrm{~h}$ to fully remove the moisture contents, and then were conditioned at $25^{\circ} \mathrm{C}$ for next $48 \mathrm{~h}$. Afterwards, using an electronic microbalance, the blank filters were measured thrice and a flask with a size of $250 \mathrm{~mL}$ was used to pour road dust with particle sizes $<53 \mu \mathrm{m}$. The road dust was pushed into the re-suspension chamber with the air pressure after its entry into the flask, and samples of dust were gathered through the outlets of $\mathrm{PM}_{2.5}$ on Teflon filters $(47 \mathrm{~mm})$ for around a minute [35]. The filters contained $\mathrm{PM}_{2.5}$ fractions that were separated from the outlets in the next step. Again, the weight was measured of all the filters thrice using electronic microbalance after the filtration of the $\mathrm{PM}_{2.5}$ fraction. At the last step, the filters were folded halfway and stored at $20^{\circ} \mathrm{C}$ by wrapping in the foil sheets of aluminum till the analysis was conducted.

Using the same technique employed in prior research studies [36], the total metal content was measured using Inductively Coupled Plasma Mass Spectroscopy (ICP-MS) subsequent aqua-regia digestion with the same approach as per earlier studies. In brief, Teflon filters holding the $\mathrm{PM}_{2.5}$ proportion of samples of dust were composed of two equal portions, with each part digested with $5 \mathrm{~mL}$ of aqua-regia mixture. In order to analyze the samples using ICP-MS, they were diluted with 2 percent nitric acid $\left(\mathrm{HNO}_{3}\right)$ solution and then analyzed using a mass spectrometer.

\subsubsection{Quality Control (QC)}

In order to ensure the quality of the analysis, all samples were collected in triplicate, including the Standard Reference Material (SRM) and filter blanks. Acids with trace concentrations are deemed appropriate for analysis and digestion. Therefore, we used trace-grade acids (nitric acid and hydrochloric acid) instead of pure acids. The National Center of Standard Materials of China (NCSMC) provided the standard reference material (GBW07451), which was acquired by the institution, i.e., Zhengzhou university (ZZU). The analysis was carried out twice so as to ensure the precision of the spiked samples and aquaregia digestion process. The recovery percentage was determined using spiked samples, SRM metal concentrations, and samples using the same method as prior studies [36]. The recoveries varied from ( $90 \%$ to $100.3 \%$ ) and ( $80 \%$ to $130.2 \%$ ) correspondingly from internal and SRM standards.

\subsection{Pollution Level Assessment}

The amount of heavy metal contamination in natural environmental samples including dust, soil, and water is determined using a number of methodologies. In this study, Pollution Index (PI) and Geoaccumulation Index ( $\mathrm{I}_{\mathrm{geo}}$ ) were used to quantify the pollution degree of heavy metals in $\mathrm{PM}_{2.5}$ fractioned road dust samples, and the conclusions were drawn. Because of the log function and constant factor of 1.5, the index of Geoaccumulation differs from various other pollution indices, and thus allows for the prevention of lithogenic effects that may be connected to variations in baseline levels [31]. However, the enrichment factor has been used to distinguish between the roles of natural and manmade sources of pollution [37]. For the purposes of computing the enrichment factor and Geoaccumulation Index, background values of $(\mathrm{Cr}, \mathrm{Ni}, \mathrm{Cu}, \mathrm{Zn}, \mathrm{As}, \mathrm{Cd}, \mathrm{Pb}$, and $\mathrm{Hg}$ ) in Zhengzhou city were obtained from a previous study [38], that are $64 \mathrm{mg} / \mathrm{kg}, 21 \mathrm{mg} / \mathrm{kg}, 14 \mathrm{mg} / \mathrm{kg}, 42 \mathrm{mg} / \mathrm{kg}$, $8 \mathrm{mg} / \mathrm{kg}, 0.08 \mathrm{mg} / \mathrm{kg}, 18 \mathrm{mg} / \mathrm{kg}$ and $0.023 \mathrm{mg} / \mathrm{kg}$, respectively. 


\subsubsection{GeoAccumulation Index (Igeo)}

In the following study [39], Geoaccumulation Index $\left(\mathrm{I}_{\text {geo }}\right)$ was used to measure heavy metal pollution in sediments. This approach has been adopted by a large number of researchers for determining the degree of heavy metal pollution in road dust and soil [40-42]. Here is the $\mathrm{I}_{\text {geo }}$ equation to calculate it:

$$
\mathrm{I}_{\text {geo }}=\log _{2} \frac{\mathrm{C}_{\mathrm{HM}}}{1.5 \times \mathrm{BV}}
$$

where $\mathrm{C}_{\mathrm{HM}}=$ heavy metals concentration, $\mathrm{BV}=$ background value of metals.

\subsubsection{Pollution Index (PI)}

The following equation was used to calculate the pollution level that defines the Pollution Index [43]:

$$
\mathrm{PI}=\frac{\mathrm{C}_{\mathrm{n}}}{\mathrm{B}_{\mathrm{n}}}
$$

where $C_{n}=$ concentration of metal, $B_{n}=$ background value of that metal.

Geoaccumulation Index ( $\left.\mathrm{I}_{\text {geo }}\right)$ and Pollution Index (PI) values and categories were classified in Table 1.

Table 1. Indexes classification for Geoaccumulation Index ( $\mathrm{I}_{\mathrm{geo}}$ and Pollution Index (PI).

\begin{tabular}{ccc}
\hline Index & Value & Category \\
\hline Geo-accumulation Index $\left(\mathrm{I}_{\text {geo }}\right)$ & $\mathrm{I}_{\text {geo }}<0$ & Unpolluted \\
& $\mathrm{I}_{\text {geo }} 0-1$ & Unpolluted-moderately \\
& $\mathrm{I}_{\text {geo }} 1-2$ & Moderately \\
& $\mathrm{I}_{\text {geo }} 2-3$ & Moderately-strongly \\
& $\mathrm{I}_{\text {geo }}-4$ & Strongly \\
Pollution Index $(\mathrm{PI})$ & $\mathrm{I}_{\text {geo }} 4-5$ & Strongly-extremely \\
& $\mathrm{I}_{\text {geo }}>5$ & Extremely \\
& $\mathrm{PI} \leq 1$ & Low \\
& $1<\mathrm{PI} \leq 3$ & Medium \\
& $\mathrm{PI}>3$ & High \\
\hline
\end{tabular}

\subsection{Health Risk Assessment}

The buildup of hazardous metals in urban road dust has the potential to have a significant adverse effect on human health. By identifying the potential exposure, the level of risk to human health presented by hazardous metals may be quantified [24]. The breathing route has been assigned a significant place among the major routes of heavy metal exposure to human body [44]. The health hazards of $\mathrm{PM}_{2.5}$ fractioned road dust samples were examined for old adults and children in this study using a two-step methodology devised by the researchers, which includes risk characterization and exposure assessment [12].

\subsubsection{Exposure Assessment}

The ongoing research has concentrated exclusively on exposure concentrations and inhalation exposure that were derived using the equation below $[23,24]$.

$$
\mathrm{MDI}_{\text {inh }}=\frac{\mathrm{C} \times \mathrm{R}_{\text {inh }} \times \mathrm{EF} \times \mathrm{ED}}{\mathrm{PEF} \times \mathrm{BW} \times \mathrm{AT}}
$$

where $\mathrm{MDI}_{\text {inh }}=$ daily average intake dose of metals for inhalation, $\mathrm{C}=$ metal concentration, $\mathrm{R}_{\text {inh }}=$ inhalation rate, $\mathrm{EF}=$ exposure frequency, $\mathrm{ED}=$ exposure duration, $\mathrm{PEF}=$ particular emission factor, $\mathrm{BW}=$ body weight, and $\mathrm{AT}=$ average time. 


\subsubsection{Risk Assessment}

The Hazards Index (HI), Hazards Quotient (HQ), and Carcinogenic Risk Index (CRI) were used to measure health risks for children and old adults. HQ and HI denote noncarcinogenic risk, but CRI denotes the chances of heavy metals being potentially carcinogenic in old adults and children. These parameters were calculated using the following equations:

$$
\begin{gathered}
\mathrm{HQ}_{\mathrm{i}}=\frac{\mathrm{MDI}}{\mathrm{RFD}} \\
\mathrm{HI}=\sum \mathrm{HQ}_{\mathrm{i}} \\
\mathrm{CR}_{\mathrm{i}}=\mathrm{MDI} \times \mathrm{SF} \\
\mathrm{CR}=\sum \mathrm{CR}_{\mathrm{i}}
\end{gathered}
$$

where $\mathrm{MDI}=$ daily metals intake dose, $\mathrm{RFD}=$ reference dose, $\mathrm{HQ}_{\mathrm{i}}=$ non-carcinogenic risk, $\mathrm{HI}=$ sum of hazard quotient, $\mathrm{CR}=$ carcinogenic risk, and $\mathrm{SF}=$ slope factor.

\section{Results and Discussions}

\subsection{Heavy Metals in Road Dust}

Except for $\mathrm{Cr}$ and $\mathrm{Ni}$, all heavy metal mean concentrations were determined to be higher than corresponding background values [38]. The amounts of $\mathrm{Hg}$ and $\mathrm{Cd}$ were found to be 14 and 7 times higher, respectively, than respective background values. Anthropogenic activity, coal and oil burning, and metal refining can all be attributed for the substantially increased levels of $\mathrm{Hg}$ and $\mathrm{Cd}[45,46]$. The mean, median, and minimum and maximum values of heavy metal concentrations are presented in Table 2.

Table 2. Heavy metal statistical values in $(\mathrm{mg} / \mathrm{kg})$.

\begin{tabular}{ccccccccc}
\hline Statistical Values & $\mathbf{C r}$ & $\mathbf{N i}$ & $\mathbf{C u}$ & $\mathbf{Z n}$ & $\mathbf{A s}$ & $\mathbf{C d}$ & $\mathbf{P b}$ & $\mathbf{H g}$ \\
\hline Background values [38] & 64 & 21 & 14 & 42 & 8 & 0.08 & 18 & 0.02 \\
Min & 19.93 & 6.77 & 7.99 & 35.53 & 8.03 & 0.12 & 19.30 & 0.03 \\
Max & 94.78 & 28.23 & 63.26 & 1319.28 & 17.49 & 3.48 & 160.62 & 1.54 \\
Mean & 46.26 & 12.51 & 25.13 & 152.35 & 11.53 & 0.56 & 52.15 & 0.32 \\
Median & 40.96 & 12.38 & 22.08 & 113.45 & 11.11 & 0.45 & 43.16 & 0.14 \\
\hline
\end{tabular}

The concentration of $\mathrm{Zn}$ was the highest among all the heavy metals, but it was lower than that of other major cities of $\mathrm{China}$. $\mathrm{Cr}, \mathrm{Cu}, \mathrm{Ni}, \mathrm{Zn}, \mathrm{Cd}$, and $\mathrm{Pb}$ concentrations in Zhengzhou were lower than all other cities of China used for the comparison, as presented in Table 3. As and $\mathrm{Hg}$ were the only two heavy metals whose concentrations in Zhengzhou were in the intermediate range compared to other cities. Their concentrations in Zhengzhou were higher than those of Beijing but lower than those of Baoji and Guangzhou [47,48]. The concentration of $\mathrm{Hg}$ was lower than in Baoji, but higher than in Beijing and Guangzhou $[3,48]$. In comparison to the background values of Zhengzhou, the concentration was considerably greater, requiring the serious response of regulators and other stakeholders to address the situation. Land use in Zhengzhou's counties had no discernible effect on mercury concentrations. This demonstrates the little effect on the propagation of mercury from road cleaning and sweeping systems and rainfall handling. The heavy metal mean concentrations in the samples were in the following order: $\mathrm{Zn}>\mathrm{Pb}$ $>\mathrm{Cr}>\mathrm{Cu}>\mathrm{Ni}>\mathrm{As}>\mathrm{Cd}>\mathrm{Hg}$. It was found that the concentration of heavy metals was maximum in commercial areas, which can be attributed to increased traffic volumes and recreational activities. Additionally, the dense concentration of high-rise structures in a region can impair spontaneous aeration, culminating into increased levels of pollutants [49]. Consequently, the presence of high-rise structures in commercial areas may be responsible for the increased concentration of pollutants. When comparing residential regions to educational and commercial sectors, the zinc concentration was greater in residential areas [50]. 
The lowest concentrations of heavy metals were found in parks and recreation places, with the exception of As and $\mathrm{Cd}$, which may be related to the distinct behaviors and properties of these metals. For $\mathrm{Cr}$, the maximum concentration was seen in commercial areas, while the lowest concentration was observed in parks. In general, the risk of the presence of toxins was higher in commercial areas. As is evident from the examples of lead and copper, commercial zones had the heaviest loads, whereas parks had the lowest.

Table 3. Comparison of concentrations with other cities of China in $(\mathrm{mg} / \mathrm{kg})$.

\begin{tabular}{ccccccccc}
\hline City & $\mathbf{C r}$ & $\mathbf{N i}$ & $\mathbf{C u}$ & $\mathbf{Z n}$ & $\mathbf{A s}$ & $\mathbf{C d}$ & $\mathbf{P b}$ & $\mathbf{H g}$ \\
\hline Zhengzhou, China (Background values) [38] & 64 & 21 & 14 & 42 & 8 & 0.08 & 18 & 0.02 \\
Zhengzhou, China & 46.26 & 12.51 & 25.13 & 152.35 & 11.53 & 0.56 & 52.15 & 0.32 \\
(Mean) & 92.1 & 32.47 & 83.12 & 280.65 & 4.88 & 0.59 & 60.88 & 0.16 \\
Beijing, China [3] & 69.33 & 25.97 & 72.13 & 219.2 & - & 0.64 & 201.82 & - \\
Beijing Park, China [51] & 126.7 & 48.8 & 123.2 & 715.3 & 19.8 & NA & 433.2 & 1.1 \\
Baoji, China [47] & 84.3 & 24.4 & 100 & 296 & - & 1.66 & 82.3 & - \\
Chengdu, China [50] & 176.22 & 41.38 & 192.36 & 1777.18 & 20.05 & 2.14 & 387.53 & 0.22 \\
Guangzhou, China [48] & 129.04 & 60.43 & 129.33 & 176.05 & - & 0.61 & 63.12 & - \\
Guiyang, China [52] & 126 & 55.9 & 123 & 394 & 13.4 & 1.1 & 103 & 0.12 \\
Nanjing, China [21] & 157 & NA & NA & NA & 8.73 & 1.24 & 246 & 0.16 \\
Shanghai, China [53] & & & & & & & &
\end{tabular}

The possible source of these heavy metals has been explained in Table 4 .

Table 4. Possible sources of heavy metals of this study.

\begin{tabular}{cc}
\hline Metals & Possible Emission Source \\
$\mathrm{Cr}$ & Fuel and incineration of lubricants [2] \\
$\mathrm{Ni}$ & Tire abrasion and fuel combustion [54] \\
$\mathrm{Cu}$ & Brake wear, coal combustion, and brake pad [55] \\
$\mathrm{Zn}$ & Brake wear, lubricants, and tire abrasion [56] \\
$\mathrm{Cd}$ & Engine wear, lubricating oil, and brake wear [57] \\
$\mathrm{As}$ & Drinkable water, foods, and tobacco [58] \\
$\mathrm{Pb}$ & Fuel, motor oil combustion, brake wear [18] \\
$\mathrm{Hg}$ & Anthropogenic and natural sources [1] \\
\hline
\end{tabular}

\subsection{Pollution Level Assessment}

Numerous approaches for measuring the degree of metal contamination in dust and soil have been proposed. While assessing the degree of accumulation of heavy metals in the $\mathrm{PM}_{2.5}$ portion of road dust, we utilized the Geoaccumulation Index $\left(\mathrm{I}_{\text {geo }}\right)$ and the Pollution Index (PI). I $\mathrm{I}_{\text {geo }}$ and PI indices have been deemed well-established techniques for measuring the impacts of heavy metals on the environment by prior research and have been used in a range of applications [41].

\subsubsection{Geoaccumulation Index $\left(\mathrm{I}_{\text {geo }}\right)$}

Each of the eight metals had their Geoaccumulation Index ( $\left.\mathrm{I}_{\text {geo }}\right)$ computed, and the results can be seen in Table 5 .

Table 5. Heavy metals' Geoaccumulation Index $\left(\mathrm{I}_{\text {geo }}\right)$ in road dust $(\mathrm{mg} / \mathrm{kg})$.

\begin{tabular}{ccccccccc}
\hline Geoaccumulation Index & $\mathbf{C r}$ & $\mathbf{N i}$ & $\mathbf{C u}$ & $\mathbf{Z n}$ & $\mathbf{A s}$ & $\mathbf{C d}$ & $\mathbf{P b}$ & $\mathbf{H g}$ \\
\hline Minimum & -2.26 & -2.21 & -1.39 & -0.82 & -0.57 & -0.02 & -0.48 & -0.02 \\
Maximum & -0.01 & -0.15 & 1.59 & 4.38 & 0.54 & 4.85 & 2.57 & 10.02 \\
Mean & -1.14 & -1.38 & 0.07 & 0.91 & -0.08 & 1.91 & 0.79 & 2.71 \\
\hline
\end{tabular}


As per the Geoaccumulation Index ( $\left.\mathrm{I}_{\text {geo }}\right)$, the exposure of chromium $(\mathrm{Cr})$, arsenic (As), and nickel (Ni) was determined to be minimal and within the range of being unpolluted. They were less than zero in their risk assessment values, demonstrating that the road dust of Zhengzhou was not contaminated with $\mathrm{Cr}$, As, and $\mathrm{Ni}$. $\mathrm{Cu}, \mathrm{Zn}$, and $\mathrm{Pb}$ contamination values were within the unpolluted to moderately polluted ranges. In the case of $\mathrm{Cd}$ and $\mathrm{Hg}$, however, the levels of pollutants, owing to air deposition and road particle absorption, were quite high. The former was determined to be in the moderately contaminated category, whilst the latter was found to be in the moderate to severe polluted range, respectively. In the following order, the Igeo values decreased: $\mathrm{Hg}>\mathrm{Cd}>\mathrm{Zn}>\mathrm{Pb}>\mathrm{Cu}>\mathrm{As}>\mathrm{Cr}>\mathrm{Ni}$.

\subsubsection{Pollution Index (PI)}

The Pollution Index (PI) was computed for each of the eight factors under study, and Table 6 shows the resulting minimum, maximum, and mean values for each of the eight elements under research.

Table 6. Heavy metals' Pollution Index (PI) in road dust $(\mathrm{mg} / \mathrm{kg})$.

\begin{tabular}{ccccccccc}
\hline Pollution Index & $\mathbf{C r}$ & $\mathbf{N i}$ & $\mathbf{C u}$ & $\mathbf{Z n}$ & $\mathbf{A s}$ & $\mathbf{C d}$ & $\mathbf{P b}$ & $\mathbf{H g}$ \\
\hline Minimum & 0.31 & 0.32 & 0.65 & 0.86 & 1.12 & 2.19 & 1.24 & 1.54 \\
Maximum & 1.33 & 1.08 & 3.97 & 16.86 & 1.81 & 25.77 & 5.74 & 48.12 \\
Mean & 0.72 & 0.59 & 1.79 & 3.62 & 1.43 & 7.15 & 2.89 & 14.25 \\
\hline
\end{tabular}

Chromium $(\mathrm{Cr})$ and nickel $(\mathrm{Ni})$ pollution index values were lower than 1, i.e., 0.72 and 0.59 , respectively, which indicated the low pollution or no pollution based on PI estimation. In the case of Copper $(\mathrm{Cu})$, arsenic $(\mathrm{As})$, and lead $(\mathrm{Pb})$, the Pollution Index showed the values $1.79,1.43$, and 2.89 , respectively and lies within the range $(1<\mathrm{PI} \leq 3)$ of moderate pollution. Zinc ( $\mathrm{Zn})$, cadmium $(\mathrm{Cd})$ and mercury $(\mathrm{Hg})$ were in the range (PI > 3) of high pollution having values 3.62, 7.15 and 14.25, respectively. So, the concerned heavy metals were $\mathrm{Zn}, \mathrm{Cd}$, and $\mathrm{Hg}$ as per the Pollution Index (PI) estimation, similar to the Geoaccumulation Index ( $\left.\mathrm{I}_{\text {geo }}\right)$, with the exception of $\mathrm{Zn}$.

\subsection{Health Risk Assessment}

For those with weak immune systems, including children and patients, harmful metalladen road dust can be highly hazardous. Children and adults have inhalation exposure to the heavy metals investigated within $\mathrm{PM}_{2.5}$ factionalized road dust samples collected from Zhengzhou. A United States Environmental Protection Agency (USEPA) health risk assessment technique was used to calculate children's and adults' health risks associated with the investigated metals, both non-carcinogenic and carcinogenic. The absence of local guideline values necessitated the use of the USEPA's model to compute health risks. The values from prior literature were used, as indicated in Table 7 , to quantify health risks using the model. RFD values were: $\mathrm{Cd}\left(1.00 \times 10^{-3}\right), \mathrm{Cr}\left(2.86 \times 10^{-5}\right), \mathrm{Cu}\left(4.02 \times 10^{-2}\right), \mathrm{Ni}$ $\left(2.06 \times 10^{-2}\right), \mathrm{Pb}\left(3.52 \times 10^{-3}\right), \mathrm{Zn}\left(3.00 \times 10^{-1}\right), \mathrm{Hg}\left(8.57 \times 10^{-5}\right)$, and $\mathrm{As}\left(1.23 \times 10^{-4}\right)$, while SF values were; As $\left(1.51 \times 10^{0}\right)$, Cd $\left(6.30 \times 10^{0}\right), \mathrm{Cr}\left(4.20 \times 10^{1}\right), \mathrm{Ni}\left(8.40 \times 10^{-1}\right)$, and $\mathrm{Pb}\left(8.50 \times 10^{-3}\right)$. A carcinogenic and non-carcinogenic health risk Hazard Index $(\mathrm{HI})$ and Hazard Quotient (HQ) was determined by using MDI $_{\text {inh }}$ values for child and adult exposition to toxic metals via resettled road dust. In the current study, eight hazardous metals were chosen for non-carcinogenic and carcinogenic health risk evaluation. 
Table 7. Carcinogenic and non-carcinogenic indices parameters.

\begin{tabular}{cccc}
\hline Parameter & Factor & Values & Units \\
\hline Average Time & AT & $365 \times \mathrm{ED}$ & Days \\
Bodyweight & BW (Child) & 15 & $\mathrm{Kg}$ \\
Bodyweight & BW (Adult) & 70 & $\mathrm{Kg}$ \\
Exposure duration & ED (Child) & 6 & Years \\
Exposure duration & ED (Adult) & 24 & Years \\
Exposure frequency & EF & 180 & Days $/$ year \\
Dust inhalation rate & $\mathrm{R}_{\text {Inh }}$ (Child) & 10 & $\mathrm{~m}^{3} /$ day \\
Dust inhalation rate & $\mathrm{R}_{\text {Inh }}$ (Adult) & 20 & $\mathrm{~m}^{3} /$ day \\
Particular emission rate & PEF & $1.36 \times 10^{9}$ & $\mathrm{~m}^{3} / \mathrm{kg}$ \\
\hline
\end{tabular}

\subsubsection{Non-Carcinogenic Risk}

The samples of dust collected from distinct land-use areas were used to determine the $\mathrm{HI}$ values and HQs in different exposure routes. As per the evaluation made according to statistical data in Table 8, the sequence of the HI values of the all the heavy elements at risk in various functional domains is as follows: commercial $>$ industrial $>$ residential $>$ educational > parks, for adults and children. Although the non-carcinogenic risk score of each heavy element was higher in magnitude for children, compared to those for adults in comparable functional domains, no statistically significant difference was detected between land-use areas. Children in industrial and commercial areas had the highest non-carcinogenic risk level, $\mathrm{HI}>0.1$, to all the heavy elements exposed to the human body by urban dust in diverse land use. Furthermore, even at low concentrations, lead $(\mathrm{Pb})$ is harmful to human health because it interferes with the development of the brain system and other organs [59]. High amounts of lead in the bloodstream, additionally, can induce bone deformities [60], particularly in youngsters, and may also have a detrimental influence on the body's neurological system, kidneys, and brain tissues [12,52]. The people, particularly youngsters, chronically exposed to polluted commercial and industrial environments require special protection and healthcare. It shows that the HI geographical distribution trend of each heavy element is the same for adults and children. Since children are more vulnerable than adults, the $\mathrm{HI}$ for a given heavy element at a given concentration is higher in children than in adults [59]. Arsenic can be present in a variety of sources, including drinkable water, foods, and tobacco. Long-term inorganic arsenic exposure, which is most typically acquired by drinking water and food, has been linked to chronic arsenic poisoning. As per a World Health Organization study, arsenic in contaminated water is easily absorbed and might cause health problems based on its metabolic form [58].

Table 8. Hazard Index (HI) values of heavy metals in different land use areas.

\begin{tabular}{|c|c|c|c|c|c|c|c|c|c|}
\hline \multicolumn{10}{|c|}{ HI } \\
\hline $\begin{array}{l}\text { Land Use } \\
\text { Areas }\end{array}$ & $\begin{array}{c}\text { Non- } \\
\text { Carcinogenic }\end{array}$ & $\mathrm{Cr}$ & $\mathrm{Ni}$ & $\mathrm{Cu}$ & Zn & As & $\mathrm{Cd}$ & $\mathrm{Pb}$ & $\mathrm{Hg}$ \\
\hline \multirow[t]{2}{*}{ Educational } & Adult & $9.12 \times 10^{-3}$ & $1.83 \times 10^{-4}$ & $4.07 \times 10^{-4}$ & $3.66 \times 10^{4}$ & $1.06 \times 10^{-2}$ & $9.90 \times 10^{-4}$ & $9.79 \times 10^{-3}$ & $1.03 \times 10^{-2}$ \\
\hline & Children & $1.71 \times 10^{-2}$ & $4.15 \times 10^{-4}$ & $3.82 \times 10^{-3}$ & $3.41 \times 10^{-3}$ & $2.42 \times 10^{-2}$ & $1.75 \times 10^{-3}$ & $9.07 \times 10^{-2}$ & $1.04 \times 10^{-2}$ \\
\hline \multirow[t]{2}{*}{ Residential } & Adult & $1.18 \times 10^{-2}$ & $1.86 \times 10^{-4}$ & $5.66 \times 10^{-4}$ & $3.92 \times 10^{-4}$ & $1.04 \times 10^{-2}$ & $5.80 \times 10^{-4}$ & $1.05 \times 10^{-2}$ & $1.56 \times 10^{-2}$ \\
\hline & Children & $2.13 \times 10^{-2}$ & $4.15 \times 10^{-4}$ & $5.29 \times 10^{-3}$ & $3.65 \times 10^{-3}$ & $2.32 \times 10^{-2}$ & $1.02 \times 10^{-3}$ & $9.64 \times 10^{-2}$ & $1.54 \times 10^{-2}$ \\
\hline \multirow[t]{2}{*}{ Parks } & Adult & $8.41 \times 10^{-3}$ & $1.64 \times 10^{-4}$ & $2.88 \times 10^{-4}$ & $2.25 \times 10^{-4}$ & $1.06 \times 10^{-2}$ & $5.41 \times 10^{-4}$ & $7.11 \times 10^{-3}$ & $7.96 \times 10^{-3}$ \\
\hline & Children & $1.54 \times 10^{-2}$ & $3.67 \times 10^{-4}$ & $2.67 \times 10^{-3}$ & $2.08 \times 10^{-3}$ & $2.43 \times 10^{-2}$ & $9.58 \times 10^{-4}$ & $6.59 \times 10^{-2}$ & $7.87 \times 10^{-3}$ \\
\hline \multirow[t]{2}{*}{ Commercial } & Adult & $1.56 \times 10^{-1}$ & $1.87 \times 10^{-4}$ & $7.44 \times 10^{-4}$ & $3.46 \times 10^{-4}$ & $9.22 \times 10^{-3}$ & $8.43 \times 10^{-4}$ & $1.36 \times 10^{-2}$ & $1.61 \times 10^{-2}$ \\
\hline & Children & $2.85 \times 10^{-2}$ & $4.16 \times 10^{-4}$ & $6.93 \times 10^{-3}$ & $3.25 \times 10^{-3}$ & $2.08 \times 10^{-2}$ & $1.51 \times 10^{-3}$ & $1.25 \times 10^{-1}$ & $1.59 \times 10^{-3}$ \\
\hline \multirow[t]{2}{*}{ Industrial } & Adult & $1.65 \times 10^{-2}$ & $2.81 \times 10^{-4}$ & $3.32 \times 10^{-4}$ & $3.17 \times 10^{-4}$ & $9.72 \times 10^{-3}$ & $5.16 \times 10^{-4}$ & $1.17 \times 10^{-2}$ & $9.77 \times 10^{-3}$ \\
\hline & Children & $3.07 \times 10^{-2}$ & $6.32 \times 10^{-4}$ & $3.06 \times 10^{-3}$ & $2.92 \times 10^{-3}$ & $2.21 \times 10^{-2}$ & $9.11 \times 10^{-4}$ & $1.06 \times 10^{-1}$ & $9.64 \times 10^{-3}$ \\
\hline
\end{tabular}




\subsubsection{Carcinogenic Risk}

The carcinogenic risk of heavy metals such as $\mathrm{Cr}, \mathrm{Ni}, \mathrm{Cd}$, and As assessed in this study revealed that the risk of cancer for $\mathrm{Ni}, \mathrm{Cd}$, and As was negligible, with average cancer risk factors of $6.57 \times 10^{-10}, 2.03 \times 10^{-10}$, and $9.66 \times 10^{-10}$, correspondingly, which fell below the lower range of threshold values $10^{-6}$ to $10^{-4}$ and are considered acceptable, as shown in Table 9. However, the higher value of As was a cause for concern and can lead to many harmful consequences such as severe damage (keratosis, leucomelanosis, and melanosis) [61]. In Zhengzhou, the cancer risk $\left(\mathrm{Cr}=1.16 \times 10^{-7}\right)$ posed to the population was possibly near to the lower limit value of $10^{-6}$, while the samples collected from inside the industrial region exhibited a cancer risk of $8.57 \times 10^{-7}$. Carcinogenic elements are classified into five functional categories based on their hazard index values. The largest cancer health hazards are associated with $\mathrm{Cr}$ and $\mathrm{Ni}$ and are found in the industrial region, followed by commercial, residential or educational, and parks, which have comparable $\mathrm{HI}$ values. Furthermore, chromium is widely used to preserve metal surfaces and construction materials, including in electrolysis, cells, polymers, and fertilizers [50]. Thus, the development of educational and commercial buildings, as well as the usage of cells and polymers in residential areas, may account for the educational, commercial, and residential areas having higher carcinogenic values of chromium $(\mathrm{Cr})$. As a result, the cancer risk associated with $\mathrm{Cr}$ exposure to people, particularly in industrial settings, should be given significant consideration. A comprehensive assessment of pollution risks for a city should also consider the health risks posed by certain toxins, such as polycyclic aromatic hydrocarbons $\left(\mathrm{PM}_{2.5}\right)$, other undetected heavy metals including $\mathrm{Fe}$ and $\mathrm{Mn}$, or in somewhat high-pollution areas (such as mining areas), in addition to the risks posed by other pollutants.

Table 9. Carcinogenic Risk (CR) values of heavy metals in different land use areas.

\begin{tabular}{|c|c|c|c|c|c|}
\hline \multicolumn{6}{|c|}{ CR } \\
\hline Land Use Areas & Carcinogenic & $\mathrm{Cr}$ & $\mathrm{Ni}$ & As & $\mathrm{Cd}$ \\
\hline Educational & Adult & $8.93 \times 10^{-8}$ & $6.31 \times 10^{-10}$ & $1.02 \times 10^{-9}$ & $2.90 \times 10^{-10}$ \\
\hline Residential & Adult & $1.12 \times 10^{-7}$ & $6.25 \times 10^{-10}$ & $9.77 \times 10^{-10}$ & $1.71 \times 10^{-10}$ \\
\hline Parks & Adult & $8.21 \times 10^{-8}$ & $5.55 \times 10^{-10}$ & $1.04 \times 10^{-9}$ & $1.60 \times 10^{-10}$ \\
\hline Commercial & Adult & $1.53 \times 10^{-7}$ & $6.33 \times 10^{-10}$ & $8.86 \times 10^{-10}$ & $2.46 \times 10^{-10}$ \\
\hline Industrial & Adult & $1.60 \times 10^{-7}$ & $9.61 \times 10^{-10}$ & $9.31 \times 10^{-10}$ & $1.50 \times 10^{-10}$ \\
\hline
\end{tabular}

\section{Conclusions}

Heavy chemicals in road dust pose a serious health risk to people. The amounts of eight heavy metals in Zhengzhou metropolitan road dust and the level of harm to human health have been evaluated in the current study. With the exception of $\mathrm{Ni}$ and $\mathrm{Cr}$, all heavy metal concentrations were determined to be greater than their background levels. The amounts of $\mathrm{Hg}$ and $\mathrm{Cd}$ were 14 and 7 times greater than their respective background levels, which shows high contamination. This alarming situation requires immediate action by all stakeholders. $\mathrm{I}_{\text {geo }}$ indicated a range of pollution categories, from strongly polluted $(\mathrm{Cd}$ and $\mathrm{Hg}$ ) to unpolluted ( $\mathrm{Ni}$ and $\mathrm{Cr}$ ). PI produced almost similar results, placing $\mathrm{Ni}$ and $\mathrm{Cr}$ in the range of low pollution or no pollution and $\mathrm{Cd}, \mathrm{Zn}$, and $\mathrm{Hg}$ in the range of high pollution, whereas Zn pollution was not indicated by Igeo.

Analyzing non-carcinogenic risk factors, the largest for children was the exposure to $\mathrm{Pb}(\mathrm{HI}>0.1)$ in commercial and industrial areas among all the land-use areas under consideration. It was further divulged that that both children and adults in Zhengzhou's commercial, residential, and park areas were highly exposed to $\mathrm{Cu}, \mathrm{Pb}$, and $\mathrm{Zn}$. The major source of these metals in such cases is vehicular exhaust. Northwestern Zhengzhou was found at the highest non-carcinogenic exposure risk to $\mathrm{Cr}$ and $\mathrm{Ni}$ from point sources. The cancer risk value of $\mathrm{Cr}$ was more likely to be at the lower limit of the threshold value, particularly in the industrial sector. As a result of the enhanced heavy metal concentrations 
in road dust as compared to background levels, it appears that the current situation is deteriorating, and people of the Zhengzhou metropolitan are at high risk of experiencing to these heavy metals.

Author Contributions: Conceptualization, M.F., Z.W. and H.W.; data curation, M.F.; formal analysis, M.F.; investigation, M.F.; methodology, M.F. and Z.W.; visualization, M.F.; writing-original draft preparation, M.F.; writing-review and editing, M.F., Z.W., H.W., Z.H. and M.I.A.; funding acquisition, Z.W.; project administration, Z.W. and H.W.; resources, Z.W.; software, Z.W. and H.W.; supervision, Z.W. and H.W.; validation, H.W. All authors have read and agreed to the published version of the manuscript.

Funding: This research was funded by National Natural Science Foundation of China, grant number 51879242 and 51739009.

Institutional Review Board Statement: Not applicable.

Informed Consent Statement: Not applicable.

Data Availability Statement: Not applicable.

Acknowledgments: The research was financially supported by the National Natural Science Foundation of China.

Conflicts of Interest: The authors affirm that they have no conflict of interest.

\section{References}

1. Faisal, M.; Wu, Z.; Wang, H.; Hussain, Z.; Shen, C. Geochemical Mapping, Risk Assessment, and Source Identification of Heavy Metals in Road Dust Using Positive Matrix Factorization (PMF). Atmosphere 2021, 12, 614. [CrossRef]

2. Ali, M.U.; Liu, G.; Yousaf, B.; Abbas, Q.; Ullah, H.; Munir, M.A.M.; Fu, B. Pollution characteristics and human health risks of potentially (eco)toxic elements (PTEs) in road dust from metropolitan area of Hefei, China. Chemosphere 2017, 181, 111-121. [CrossRef]

3. Men, C.; Liu, R.; Xu, F.; Wang, Q.; Guo, L.; Shen, Z. Pollution characteristics, risk assessment, and source apportionment of heavy metals in road dust in Beijing, China. Sci. Total Environ. 2018, 612, 138-147. [CrossRef]

4. Lanzerstorfer, C. Toward more intercomparable road dust studies. Crit. Rev. Environ. Sci. Technol. 2021, 51, 826-855. [CrossRef]

5. Huang, H.; Lin, C.; Yu, R.; Yan, Y.; Hu, G.; Li, H. Contamination assessment, source apportionment and health risk assessment of heavy metals in paddy soils of Jiulong River Basin, Southeast China. RSC Adv. 2019, 9, 14736-14744. [CrossRef]

6. Kastury, F.; Smith, E.; Juhasz, A. A critical review of approaches and limitations of inhalation bioavailability and bioaccessibility of metal(loid)s from ambient particulate matter or dust. Sci. Total Environ. 2017, 574, 1054-1074. [CrossRef] [PubMed]

7. Wiseman, C.L.; Levesque, C.; Rasmussen, P.E. Characterizing the sources, concentrations and resuspension potential of metals and metalloids in the thoracic fraction of urban road dust. Sci. Total Environ. 2021, 786, 147467. [CrossRef] [PubMed]

8. Zhu, X.; Yu, W.; Li, F.; Liu, C.; Ma, J.; Yan, J.; Wang, Y.; Tian, R. Spatio-temporal distribution and source identification of heavy metals in particle size fractions of road dust from a typical industrial district. Sci. Total Environ. 2021, 780, 146357. [CrossRef] [PubMed]

9. Gujre, N.; Rangan, L.; Mitra, S. Occurrence, geochemical fraction, ecological and health risk assessment of cadmium, copper and nickel in soils contaminated with municipal solid wastes. Chemosphere 2021, 271, 129573. [CrossRef]

10. Shakerkhatibi, M.; Seifipour, H.; Sabeti, Z.; Kahe, D.; Jafarabadi, M.A.; Benis, K.Z.; Hajaghazadeh, M. Correlation of ambient particulate matters (PM10, PM2.5) with respiratory hospital admissions: A case-crossover study in Urmia, Iran. Hum. Ecol. Risk Assess. Int. J. 2021, 27, 2184-2201. [CrossRef]

11. Khan, R.K.; Strand, M.A. Road dust and its effect on human health: A literature review. Epidemiol. Health 2018, 40 , e2018013. [CrossRef]

12. Rahman, M.S.; Khan, M.; Jolly, Y.; Kabir, J.; Akter, S.; Salam, A. Assessing risk to human health for heavy metal contamination through street dust in the Southeast Asian Megacity: Dhaka, Bangladesh. Sci. Total Environ. 2019, 660, 1610-1622. [CrossRef] [PubMed]

13. Alves, C.; Evtyugina, M.; Vicente, A.; Vicente, E.; Nunes, T.; Silva, P.; Duarte, M.; Pio, C.; Amato, F.; Querol, X. Chemical profiling of PM10 from urban road dust. Sci. Total Environ. 2018, 634, 41-51. [CrossRef] [PubMed]

14. Chen, S.; Zhang, X.; Lin, J.; Huang, J.; Zhao, D.; Yuan, T.; Huang, K.; Luo, Y.; Jia, Z.; Zang, Z.; et al. Fugitive Road Dust PM2.5 Emissions and Their Potential Health Impacts. Environ. Sci. Technol. 2019, 53, 8455-8465. [CrossRef] [PubMed]

15. Chow, J.C.; Watson, J.; Lu, Z.; Lowenthal, D.H.; Frazier, C.A.; Solomon, P.A.; Thuillier, R.H.; Magliano, K. Descriptive analysis of PM2.5 and PM10 at regionally representative locations during SJVAQS/AUSPEX. Atmos. Environ. 1996, 30, 2079-2112. [CrossRef]

16. Amato, F.; Pandolfi, M.; Escrig, A.; Querol, X.; Alastuey, A.; Pey, J.; Perez, N.; Hopke, P. Quantifying road dust resuspension in urban environment by Multilinear Engine: A comparison with PMF2. Atmos. Environ. 2009, 43, 2770-2780. [CrossRef] 
17. Zhao, H.; Shao, Y.; Yin, C.; Jiang, Y.; Li, X. An index for estimating the potential metal pollution contribution to atmospheric particulate matter from road dust in Beijing. Sci. Total Environ. 2016, 550, 167-175. [CrossRef]

18. Lough, G.C.; Schauer, J.J.; Park, J.-S.; Shafer, M.M.; DeMinter, J.T.; Weinstein, J.P. Emissions of Metals Associated with Motor Vehicle Roadways. Environ. Sci. Technol. 2005, 39, 826-836. [CrossRef]

19. Alshetty, V.D.; Kuppili, S.K.; Nagendra, S.S.; Ramadurai, G.; Sethi, V.; Kumar, R.; Sharma, N.; Namdeo, A.; Bell, M.; Goodman, P.; et al. Characteristics of tail pipe (Nitric oxide) and resuspended dust emissions from urban roads-A case study in Delhi city. $J$. Transp. Health 2020, 17, 100653. [CrossRef]

20. Lurie, K.; Nayebare, S.R.; Fatmi, Z.; Carpenter, D.O.; Siddique, A.; Malashock, D.; Khan, K.; Zeb, J.; Hussain, M.M.; Khatib, F.; et al. $\mathrm{PM}_{2.5}$ in a megacity of Asia (Karachi): Source apportionment and health effects. Atmos. Environ. 2019, 202, 223-233. [CrossRef]

21. Liu, E.; Wang, X.; Liu, H.; Liang, M.; Zhu, Y.; Li, Z. Chemical speciation, pollution and ecological risk of toxic metals in readily washed off road dust in a megacity (Nanjing), China. Ecotoxicol. Environ. Saf. 2019, 173, 381-392. [CrossRef]

22. Han, N.M.M.; Latif, M.T.; Othman, M.; Dominick, D.; Mohamad, N.; Juahir, H.; Tahir, N.M. Composition of selected heavy metals in road dust from Kuala Lumpur city centre. Environ. Earth Sci. 2014, 72, 849-859. [CrossRef]

23. Rehman, A.; Liu, G.; Yousaf, B.; Rehman, M.Z.U.; Ali, M.U.; Rashid, M.S.; Farooq, M.R.; Javed, Z. Characterizing pollution indices and children health risk assessment of potentially toxic metal(oid)s in school dust of Lahore, Pakistan. Ecotoxicol. Environ. Saf. 2020, 190, 110059. [CrossRef]

24. Jayarathne, A.; Egodawatta, P.; Ayoko, G.A.; Goonetilleke, A. Assessment of ecological and human health risks of metals in urban road dust based on geochemical fractionation and potential bioavailability. Sci. Total Environ. 2018, 635, 1609-1619. [CrossRef]

25. The State Council on the General Planning of Zhengzhou City. Available online: http://www.gov.cn/zwgk/2010-08/23/content_ 1686432.htm (accessed on 23 October 2010).

26. Zhengzhou Local History Office. Available online: http://szb.zhengzhou.gov.cn/html/2012/zzgl_1219/57.html (accessed on 11 February 2016).

27. Zhengzhou Local History Office. Available online: http://szb.zhengzhou.gov.cn/zzgl/1142969.jhtml (accessed on 18 April 2014).

28. Zhengzhou Statistical Bulletin on National Economic and Social Development 2019. Available online: http://tjj.zhengzhou.gov. $\mathrm{cn}$ /tjgb/3112732.jhtml (accessed on 7 February 2021).

29. Zhengzhou Municipal Public Bureau. Available online: http:/ /zzga.zhengzhou.gov.cn/jfgg/3460061.jhtml (accessed on 24 June 2020).

30. China Electric Vehicle Association. The Number of Electric Vehicles in Zhengzhou Has Exceeded 3 Million. Available online: http:/ / www.ceva.org.cn/cn/viewnews/20191015/20191015102917.htm (accessed on 15 October 2019).

31. Othman, M.; Latif, M.T.; Matsumi, Y. The exposure of children to PM2.5 and dust in indoor and outdoor school classrooms in Kuala Lumpur City Centre. Ecotoxicol. Environ. Saf. 2019, 170, 739-749. [CrossRef] [PubMed]

32. Tian, S.; Liang, T.; Li, K. Fine road dust contamination in a mining area presents a likely air pollution hotspot and threat to human health. Environ. Int. 2019, 128, 201-209. [CrossRef] [PubMed]

33. Wang, Q.; Lu, X.; Pan, H. Analysis of heavy metals in the re-suspended road dusts from different functional areas in Xi'an, China. Environ. Sci. Pollut. Res. 2016, 23, 19838-19846. [CrossRef] [PubMed]

34. Ramírez, O.; de la Campa, A.M.S.; Amato, F.; Moreno, T.; Silva, L.; de la Rosa, J.D. Physicochemical characterization and sources of the thoracic fraction of road dust in a Latin American megacity. Sci. Total Environ. 2019, 652, 434-446. [CrossRef] [PubMed]

35. Kong, S.; Lu, B.; Ji, Y.; Zhao, X.; Bai, Z.; Xu, Y.; Liu, Y.; Jiang, H. Risk assessment of heavy metals in road and soil dusts within PM2.5, PM10 and PM100 fractions in Dongying city, Shandong Province, China. J. Environ. Monit. 2012, 14, 791-803. [CrossRef]

36. Kastury, F.; Smith, E.; Karna, R.R.; Scheckel, K.; Juhasz, A. Methodological factors influencing inhalation bioaccessibility of metal(loid)s in PM2.5 using simulated lung fluid. Environ. Pollut. 2018, 241, 930-937. [CrossRef]

37. Chen, H.; Lu, X.; Li, L.Y.; Gao, T.; Chang, Y. Metal contamination in campus dust of Xi'an, China: A study based on multivariate statistics and spatial distribution. Sci. Total Environ. 2014, 484, 27-35. [CrossRef] [PubMed]

38. Hangxin, C.; Kuo, L.; Min, L.; Ke, Y.; Fei, L.; Xiaomeng, C. Background and benchmark values of chemical elements in urban soils in China. Geoscience Frontiers. 2014, 21, 265. [CrossRef]

39. Müller, G. Index of Geo-Accumulation in Sediments of the Rhine River-ScienceOpen. Available online: https://www. scienceopen.com/document?vid=4b875795-5729-4c05-9813-64951e2ca488 (accessed on 1 April 2021).

40. Adimalla, N.; Wang, H. Distribution, contamination, and health risk assessment of heavy metals in surface soils from northern Telangana, India. Arab. J. Geosci. 2018, 11, 684. [CrossRef]

41. Faiz, Y.; Tufail, M.; Javed, M.T.; Chaudhry, M.; Siddique, N. Road dust pollution of Cd, Cu, Ni, Pb and Zn along Islamabad Expressway, Pakistan. Microchem. J. 2009, 92, 186-192. [CrossRef]

42. Trujillo-González, J.M.; Torres-Mora, M.A.; Keesstra, S.; Brevik, E.C.; Jiménez-Ballesta, R. Heavy metal accumulation related to population density in road dust samples taken from urban sites under different land uses. Sci. Total Environ. 2016, 553, 636-642. [CrossRef]

43. Lu, X.; Wang, L.; Lei, K.; Huang, J.; Zhai, Y. Contamination assessment of copper, lead, zinc, manganese and nickel in street dust of Baoji, NW China. J. Hazard. Mater. 2009, 161, 1058-1062. [CrossRef] [PubMed]

44. Hernández-Pellón, A.; Nischkauer, W.; Limbeck, A.; Fernandez-Olmo, I. Metal(loid) bioaccessibility and inhalation risk assessment: A comparison between an urban and an industrial area. Environ. Res. 2018, 165, 140-149. [CrossRef] [PubMed] 
45. Al-Khashman, O.A. Determination of metal accumulation in deposited street dusts in Amman, Jordan. Environ. Geochem. Health 2007, 29, 1-10. [CrossRef] [PubMed]

46. Wang, G.; Xia, D.; Liu, X.; Chen, F.; Yu, Y.; Yang, L.; Chen, J.; Zhou, A. Spatial and temporal variation in magnetic properties of street dust in Lanzhou City, China. Sci. Bull. 2008, 53, 1913-1923. [CrossRef]

47. Lu, X.; Wang, L.; Li, L.; Lei, K.; Huang, L.; Kang, D. Multivariate statistical analysis of heavy metals in street dust of Baoji, NW China. J. Hazard. Mater. 2010, 173, 744-749. [CrossRef]

48. Huang, M.; Wang, W.; Chan, C.Y.; Cheung, K.C.; Man, Y.B.; Wang, X.; Wong, M.H. Contamination and risk assessment (based on bioaccessibility via ingestion and inhalation) of metal(loid)s in outdoor and indoor particles from urban centers of Guangzhou, China. Sci. Total Environ. 2014, 479-480, 117-124. [CrossRef] [PubMed]

49. Giyasov, B.; Giyasova, I. The Impact of High-Rise Buildings on the Living Environment. E3S Web Conf. 2018, 33, 01045. [CrossRef]

50. Li, H.-H.; Chen, L.-J.; Yu, L.; Guo, Z.-B.; Shan, C.-Q.; Lin, J.-Q.; Gu, Y.-G.; Yang, Z.-B.; Yang, Y.-X.; Shao, J.-R.; et al. Pollution characteristics and risk assessment of human exposure to oral bioaccessibility of heavy metals via urban street dusts from different functional areas in Chengdu, China. Sci. Total Environ. 2017, 586, 1076-1084. [CrossRef]

51. Du, Y.; Gao, B.; Zhou, H.; Ju, X.; Hao, H.; Yin, S. Health Risk Assessment of Heavy Metals in Road Dusts in Urban Parks of Beijing, China. Procedia Environ. Sci. 2013, 18, 299-309. [CrossRef]

52. Duan, Z.; Wang, J.; Xuan, B.; Cai, X.; Zhang, Y. Spatial Distribution and Health Risk Assessment of Heavy Metals in Urban Road Dust of Guiyang, China. Nat. Environ. Pollut. Technol. 2018, 17, 407-412.

53. Wang, J.; Chen, Z.; Sun, X.; Shi, G.; Xu, S.; Wang, D.; Wang, L. Quantitative spatial characteristics and environmental risk of toxic heavy metals in urban dusts of Shanghai, China. Environ. Earth Sci. 2009, 59, 645-654. [CrossRef]

54. Dehghani, S.; Moore, F.; Keshavarzi, B.; Beverley, A.H. Health risk implications of potentially toxic metals in street dust and surface soil of Tehran, Iran. Ecotoxicol. Environ. Saf. 2017, 136, 92-103. [CrossRef]

55. Pant, P.; Baker, S.J.; Shukla, A.; Maikawa, C.; Pollitt, K.G.; Harrison, R.M. The PM 10 fraction of road dust in the UK and India: Characterization, source profiles and oxidative potential. Sci. Total Environ. 2015, 530-531, 445-452. [CrossRef]

56. Hwang, H.-M.; Fiala, M.; Park, D.; Wade, T.L. Review of pollutants in urban road dust and stormwater runoff: Part 1. Heavy metals released from vehicles. Int. J. Urban Sci. 2016, 20, 334-360. [CrossRef]

57. Gope, M.; Masto, R.E.; George, J.; Hoque, R.R.; Balachandran, S. Bioavailability and health risk of some potentially toxic elements $(\mathrm{Cd}, \mathrm{Cu}, \mathrm{Pb}$ and $\mathrm{Zn})$ in street dust of Asansol, India. Ecotoxicol. Environ. Saf. 2017, 138, 231-241. [CrossRef] [PubMed]

58. Chung, J.-Y.; Yu, S.-D.; Hong, Y.-S. Environmental Source of Arsenic Exposure. J. Prev. Med. Public Health 2014, 47, $253-257$. [CrossRef] [PubMed]

59. Ackah, M. Soil elemental concentrations, geoaccumulation index, non-carcinogenic and carcinogenic risks in functional areas of an informal e-waste recycling area in Accra, Ghana. Chemosphere 2019, 235, 908-917. [CrossRef] [PubMed]

60. Mohmand, J.; Eqani, S.A.M.A.S.; Fasola, M.; Alamdar, A.; Mustafa, I.; Ali, N.; Liu, L.; Peng, S.; Shen, H. Human exposure to toxic metals via contaminated dust: Bio-accumulation trends and their potential risk estimation. Chemosphere 2015, 132, 142-151. [CrossRef] [PubMed]

61. Shil, S.; Singh, U.K. Health risk assessment and spatial variations of dissolved heavy metals and metalloids in a tropical river basin system. Ecol. Indic. 2019, 106, 105455. [CrossRef] 